\title{
Hydrofluoric acid concentration and etching time on bond strength to lithium
}

\section{disilicate glass-ceramic}

\author{
Influência da concentração e tempo de condicionamento na resistência de união de cerâmicas de \\ dissilicato de lítio \\ Influencia de la concentración y el tiempo de acondicionamiento en la fuerza de anillado de las \\ cerámicas de litio disilicado
}

Received: 12/15/2021 | Reviewed: 12/20/2021 | Accept: 12/24/2021| Published: 12/26/2021

\author{
Roberta Pinto Pereira \\ ORCID: https://orcid.org/0000-0003-3479-9992 \\ Federal University of Santa Catarina, Brazil \\ E-mail: robertapkrohling@gmail.com \\ Renan Dias Carvalho \\ ORCID: https://orcid.org/0000-0002-9128-674X \\ Federal University of Santa Catarina, Brazil \\ E-mail: renandiasc@gmail.com \\ Carolina Mayumi Cavalcanti Taguchi \\ ORCID: https://orcid.org/0000-0002-1204-3193 \\ Federal University of Santa Catarina, Brazil \\ E-mail: cm.taguchi@gmail.com \\ Sylvio Monteiro Jr. \\ ORCID: https://orcid.org/0000-0002-5873-4408 \\ Federal University of Santa Catarina, Brazil \\ E-mail: sylviomj@gmail.com \\ Renata Gondo \\ ORCID: https://orcid.org/0000-0002-7340-7333 \\ Federal University of Santa Catarina, Brazil \\ E-mail: renata.gondo@ufsc.br
}

\begin{abstract}
The objective of this study to evaluate the effect of different HF concentrations and etching times on the microshear bond strength $(\mu \mathrm{SBS})$ of LD to resin cement. Forty LD sections $(8 \times 8 \mathrm{~mm})$ of 3 -mm thickness were randomly distributed $(\mathrm{n}=10)$ in accordance with the HF concentration (5 or 10\%) and surface etching time $(20 \mathrm{or} 60 \mathrm{sec})$. The specimens were silanized and received an air-thinned layer of a light-curable adhesive. Six translucent tubes (0.8-mm diameter and 1-mm height) were positioned over each LD section, filled with resin cement and light-cured. After $24 \mathrm{~h}$ of storage, the tubes were carefully removed and the specimens were submitted to the $\mu$ SBS test. The results submitted to a two-way analysis of variance and Sidak post hoc test $(\alpha=.05)$. Representative HF-etched specimens and one non-etched LD specimen were observed under a field-emission scanning electron microscope. The interaction between the HF concentrations and etching times was not significant $(\mathrm{p}=0.075)$. No significant differences were observed regarding HF concentrations and etching times ( $\mathrm{p}=0.06$ and $\mathrm{p}=0.059$, respectively). Surfaces of specimens etched with $10 \% \mathrm{HF}$ for $60 \mathrm{sec}$ were found with grooves and microcracks. The $\mu \mathrm{SBS}$ of LD to resin cement was not significantly influenced by different HF concentrations and etching times; however, the LD surface morphology was found considerably modified.
\end{abstract}

Keywords: Ceramics; Hydrofluoric acid; Cementation; Microshear.

\section{Resumo}

Avaliar o efeito de diferentes concentrações de HF e tempos de condicionamento na resistência de união ao microcisalhamento ( $\mu \mathrm{SBS})$ do DL ao cimento resinoso. Quarenta cortes DL $(8 \times 8 \mathrm{~mm})$ de $3 \mathrm{~mm}$ de espessura foram distribuídos aleatoriamente $(n=10)$ de acordo com a concentração de HF $(5$ ou $10 \%)$ e tempo de condicionamento superficial (20 ou $60 \mathrm{seg}$ ). Os espécimes foram silanizados e receberam uma camada fina de adesivo fotopolimerizável. Seis tubos translúcidos $(0,8 \mathrm{~mm}$ de diâmetro e $1 \mathrm{~mm}$ de altura) foram posicionados sobre cada corte de DL, preenchidos com cimento resinoso e fotopolimerizados. Após 24 horas de armazenamento, os tubos foram cuidadosamente retirados e os corpos-de-prova submetidos ao teste $\mu$ SBS. Os resultados foram submetidos à análise de variância bidirecional e teste post hoc de Sidak $(\alpha=0,05)$. Amostras representativas condicionadas com HF e uma amostra DL não condicionada foram observadas em um microscópio eletrônico de varredura. A interação entre 
as concentrações de HF e os tempos de condicionamento não foi significativa ( $p=0,075$ ). Não foram observadas diferenças significativas em relação às concentrações de HF e tempos de condicionamento $(p=0,06 ; p=0,059)$. Nas superfícies tratadas com $10 \%$ de HF por 60 segundos foram encontradas sulcos e microfissuras. O $\mu$ SBS de DL para o cimento resinoso não foi significativamente influenciado por diferentes concentrações de HF e tempos de condicionamento; no entanto, a morfologia da superfície DL foi consideravelmente modificada. Palavras-chave: Cerâmica; Ácido fluorídrico; Cimentação; Microcisalhamento.

\section{Resumen}

Evaluar el efecto de diferentes concentraciones de HF y tiempos de grabado sobre la fuerza de unión al microcizallamiento ( $\mu \mathrm{SBS})$ del DL al cemento de resina. Se distribuyeron aleatoriamente cuarenta secciones DL $(8 \mathrm{x} 8 \mathrm{~mm})$ de $3 \mathrm{~mm}$ de espesor $(\mathrm{n}=10)$ de acuerdo con la concentración de HF (5 o 10\%) y el tiempo de acondicionamiento de la superficie (20 e 60 segundos). Las muestras se silanizaron y recibieron una fina capa de adhesivo fotopolimerizable. Se colocaron seis tubos translúcidos $(0,8 \mathrm{~mm}$ de diámetro y $1 \mathrm{~mm}$ de altura) sobre cada sección de DL, se rellenaron con cemento de resina y se fotopolimerizaron. Después de 24 horas de almacenamiento, los tubos se retiraron con cuidado y las muestras se sometieron a la prueba $\mu$ SBS. Los resultados se sometieron a análisis de varianza bidireccional y prueba post hoc de Sidak $(\alpha=0,05)$. Se observaron muestras representativas acondicionadas con HF y una muestra DL no acondicionada bajo un microscopio electrónico de barrido. La interacción entre las concentraciones de HF y los tiempos de acondicionamiento no fue significativa $(\mathrm{p}=0.075)$. No se observaron diferencias significativas con respecto a las concentraciones de HF y los tiempos de acondicionamiento ( $p=0.06 ; p=$ 0.059). En superficies tratadas con $\mathrm{HF}$ al $10 \%$ durante 60 segundos, se encontraron surcos y microfisuras. $\mu$ SBS de DL para cemento resinoso no fue influenciado significativamente por diferentes concentraciones de HF y tiempos de acondicionamiento; sin embargo, la morfología de la superficie DL se ha modificado considerablemente. Palabras clave: Cerámica; Ácido fluorhídrico; Cementación; Microcizalla.

\section{Introduction}

Glass-ceramic is widely used in restorative dentistry due to its high compressive strength, wear resistance, surface gloss, color stability, biocompatibility, and low thermal conductivity (Edelhoff, et al., 2018; Gracis, et al., 2015; Santos, et al., 2015; Mörmann, et al., 2013; Denry \& Kelly, 2014; Alghazzawi, et al., 2012). Some factors such as the pretreatment of tooth substrates and ceramic inner surfaces are associated with the longevity of bonded indirect restorations (Haddad, et al., 2011). An adequate surface treatment has a great influence on the tensile bond strength between lithium disilicate glass-ceramic (LD) and resin cement (Aboushelib \& Sleem, 2014; Vila-Nova et al., 2019).

The strategies purposed for ceramic surface treatment can be distinguished in accordance with their, mechanism of action: mechanical, chemical, or chemo-mechanical (Borges, et al., 2003). The mechanical alteration of the surface through hydrofluoric acid (HF) etching figures as the most effective approach for glass-ceramic reinforced by lithium crystals (Denry \& Kelly, 2014; Bajraktarova, et al., 2018). HF dissolves glassy matrix and exposes the embedded LD crystal (Sundfeld, et al., 2015; Blatz, et al., 2003; Guarda, et al., 2013), which increases micromechanical interlocking with resin cement e results in high and stable bond strength values (Venturini, et al., 2015; Bottino, et al., 2015; Sundfeld, et al., 2018). However, the pattern of matrix dissolution depends on HF concentration, etching time, and ceramic composition (Aboushelib \& Sleem, 2014; Peumans, et al., 2016).

A wide variety of HF concentrations such as 1, 2,5, 5, 10 and 15\% (Haddad, et al., 2011; Sundfeld, et al., 2015; Pattanaik \& Wadkar, 2011; Kalavacharla, et al., 2015; Sundfeld, et al., 2016; Puppin-Rontani, et al., 2017; Lopes, et al., 2019) and etching times of 20, 40, 60 and $120 \mathrm{sec}$ (Pattanaik \& Wadkar, 2011; Kalavacharla, et al., 2015; Puppin-Rontani, et al., 2017; Mokhtarpour, et al., 2017) has been reported by several in vitro studies on glass-ceramics. The effect of HF on the glassceramic surface depends on concentration and time; however, a consensual etching protocol for LD has not yet been established. Therefore, this study aimed to evaluate the effect of different HF concentrations (5\% or 10\%) and etching times (20 sec or $60 \mathrm{sec}$ ) on the bond strength to resin cement and the surface morphology of LD. The null hypotheses tested were that 1) HF concentrations and 2) etching times did not have an influence on the microshear bond strength $\mu$ SBS to LD. 


\section{Methodology}

This is an experimental, in vitro, quantitative and qualitative study. LD blocks were cut in $8 \times 8 \mathrm{~mm}$ sections of 3-mm thickness by using a water-cooled and low-speed diamond saw (Isomet 1000, Buehler, Lake Bluff, IL, USA). LD sections were ultrasonically cleaned with distilled water for $10 \mathrm{~min}$ and fired following the crystallization program recommended by the manufacturer. After cooling, the specimens were positioned in polyvinyl chloride (PVC) plastic rings and embedded in epoxy resin (Epo-Thin Resin, Buehler, Lake Buff, IL, USA). Each specimen was mechanically wet polished (Struers DP-10, Panambra, São Paulo, SP, Brazil) with 600-, 800- and 1200-grit silicon carbide paper (Acqua Flex-Norton, São Paulo, SP, Brazil) to establish a uniform surface and ultrasonically cleaned.

The LD specimens were randomly distributed in four groups $(\mathrm{n}=10)$ in accordance with the HF concentration $(5 \%$ or $10 \%)$ and surface etching time $(20 \mathrm{sec}$ or $60 \mathrm{sec})$. After rinsing with air/water spray for $30 \mathrm{sec}$ and air-drying, the LD specimens were silanized and left undisturbed for $60 \mathrm{sec}$. A single layer of a light-curable adhesive was applied, air-thinned and light-cured for $20 \mathrm{sec}$ using a light-emitting diode (LED) unit (Bluephase N, Ivoclar Vivadent, Schaan, Liechtenstein) with an output of 1,000 $\mathrm{mW} / \mathrm{cm}^{2}$. Each LD specimen was covered with an acid-resistant and double-sided adhesive tape perforated with six equally distant 1-mm-diameter holes to delimit the bonding áreas. Translucent polyethylene Tygon tubes (Tygon Medical Tubing, Saint-Gobain, Akron, OH, USA) with an internal diameter of $0.8 \mathrm{~mm}$ and 1-mm height were positioned over the lumen of the tape perforations. After careful insertion of light-curable resin cement into each tube, a Mylar strip was gently pressed over the filled tube to avoid displacement and light-cured for $40 \mathrm{sec}$ using the LED unit. After $24 \mathrm{~h}$ of storage in distilled water at $37{ }^{\circ} \mathrm{C}$, the tubes were carefully removed using a sharp blade to expose the resin cement cylinders. Specimens were examined under magnification to exclude possible irregularities at the bonding area.

The PVC rings were attached to a universal testing machine (4444, Instron, Canton, MA, USA). A sharpened stylus was used to apply shear forces on to the side of each resin cement cylinder at a crosshead speed of $0.5 \mathrm{~mm} / \mathrm{min}$ until failure. The $\mu$ SBS results were calculated in $\mathrm{MPa}$ by dividing the load at the failure by the bonding surface area $\left(\mathrm{mm}^{2}\right)$. Since the Kolmogorov-Smirnov showed normal data distribution $(\mathrm{p}=0.082)$ and the Levene test demonstrated the equality of variances $(\mathrm{p}=0.062)$, the results were submitted to two-way analysis of variance (ANOVA) and Sidak multi-comparison post hoc test $(\mathrm{p}<0.05)$ (SPSS 22, IBM, Chicago, IL, USA).

Debonded specimens were examined by using a stereomicroscope under 20X magnification (SteREO Discovery V12, Carl Zeiss, Jena, Alemanha) and cohesive failures in resin cement were excluded. Representative HF-etched specimens and one non-etched LD specimen were mounted on aluminum stubs with adhesive carbon tape (PELCO Carbon Conductive Tape, Ted Pella, Redding, CA, USA), coated with gold-palladium by means of a sputter-coater (SCD 050, Bal-Tec AG, Pfäffikon, Switzerland) at $40 \mathrm{~mA}$ for $40 \mathrm{sec}$ and observed under a field-emission scanning electron microscope (SEM) (JSM- 6701F, JEOL, Tokyo, Japan) at an accelerating voltage of $8.0 \mathrm{kV}$ and up to 2,000X magnification.

\section{Results}

The mean $\mu$ SBS values are shown 9195734173 in Table 1. The interaction between the HF concentrations and etching times was found not significant $(\mathrm{p}=0.075)$. No significant differences were observed regarding HF concentrations and etching times $(\mathrm{p}=0.06$ and $\mathrm{p}=0.059$, respectively). Regarding each etching time, no significant difference was found between different $\mathrm{HF}$ concentrations $(\mathrm{p}=0.13$ and $\mathrm{p}=0.31)$. 
Table 1 - Means of $\mu$ SBS (MPa) for all groups.

\begin{tabular}{ccc}
\hline & \multicolumn{2}{c}{ Etching time } \\
\cline { 2 - 3 } HF concentration & $20 \mathrm{sec}$ & $60 \mathrm{sec}$ \\
\hline $5 \%$ & $26.07( \pm 12.97)^{\mathrm{Aa}}$ & $22.61( \pm 10.36)^{\mathrm{Aa}}$ \\
$10 \%$ & $21.87( \pm 8.91)^{\mathrm{Aa}}$ & $24.18( \pm 12.00)^{\mathrm{Aa}}$ \\
\hline
\end{tabular}

*Means with identical superscript uppercase letters in each column are not significantly different $(\mathrm{p}<0.05)$.

*Means with identical superscript lowercase letters in each row are not significantly different $(\mathrm{p}<0.05)$.

Source: Authors.

The SEM evaluation revealed different surface morphology of LD in function of HF concentration and etching time. Etching with 5\% HF for $60 \mathrm{sec}$ resulted in a slight increase of glassy matrix removal in comparison with $20 \mathrm{sec}$ (Fig. 1A-D).

Figure 1 - SEM photomicrographs of LD surfaces etched with 5\% HF during $20 \mathrm{sec}$ (A and B) and 60 sec (C and D). Original magnifications $=850 \mathrm{X}$ and $2,000 \mathrm{X}$.

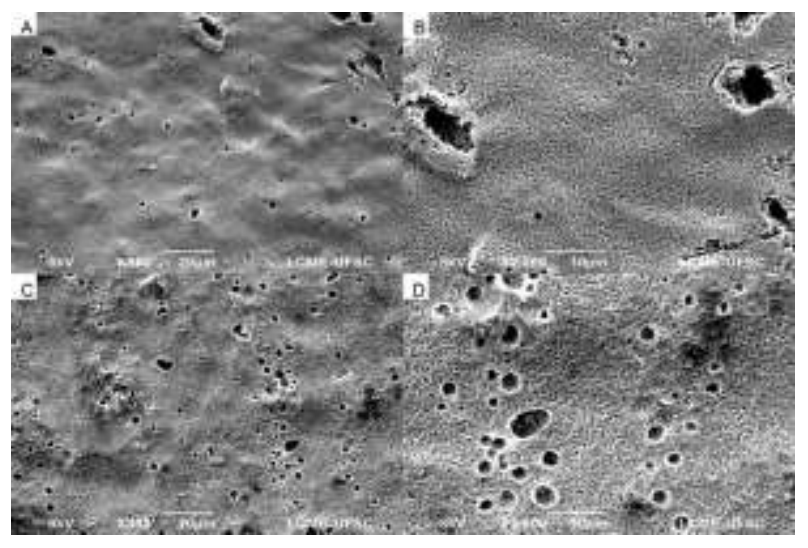

Source: Personal archives (2021).

Surface etching with $10 \%$ HF induced glassy matrix removal and consequent exposure of LD crystals (Fig. 2A-D).

Figure 2 - SEM photomicrographs of LD surfaces etched with 10\% HF during 20 sec (A and B) and 60 sec (C and D). Original magnifications $=850 \mathrm{X}$ and $2,000 \mathrm{X}$.

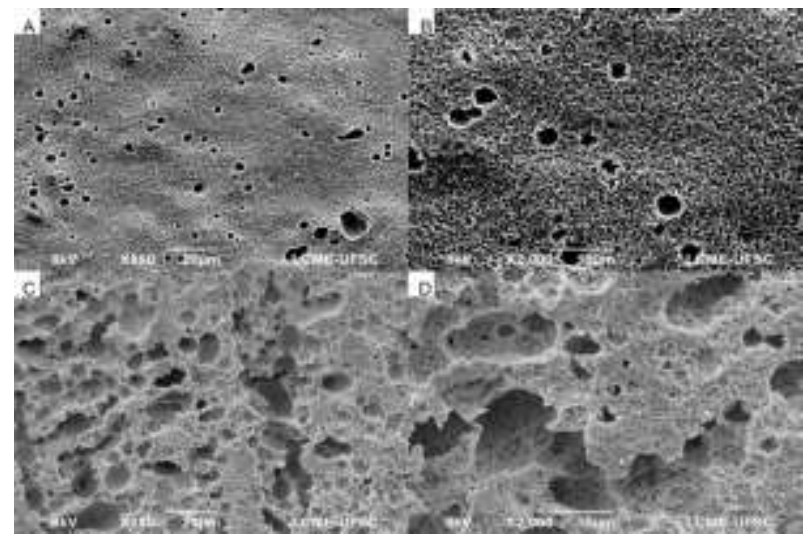

Source: Personal archives (2021). 
The morphology of a non-etched LD specimen is characterized by a smooth surface without retentive features (Fig. 3A), while LD surfaces etched with 5\% $\mathrm{HF}$ and $10 \% \mathrm{HF}$ for $60 \mathrm{sec}$ were observed with noticeable removal of the glassy matrix (Fig. 3B and 3C).

Figure 3 - SEM photomicrographs of LD surfaces non-etched (A), etched with 5\% HF (B) and $10 \%$ HF (C) for 60 sec. Original magnification $=850 \mathrm{X}$.

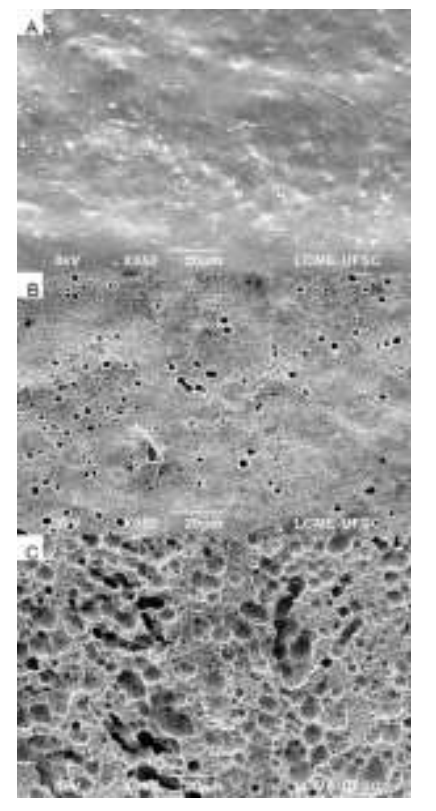

Source: Personal archives (2021).

\section{Discussion}

HF etching is recommended for LD surface treatment due to its selective dissolution of the glassy matrix, which exposes 0.5 to $4 \mu \mathrm{m}$-length crystals and creates microporosities that increases surface area and resin cement interlocking. Although the manufacturer of IPS e.max CAD (Ivoclar Vivadent, Schaan, Liechtenstein) specifically recommends the use of HF 5\% for $20 \mathrm{sec}$, many clinicians extend the etching time of LD restorations. This misunderstanding may be associated with the former surface treatment protocol of feldspathic ceramics and the reduced commercial availability of HF $5 \%$.

Since the results of this study showed that different HF concentrations and etching times have no significant effect on bond strength to resin cement, the null hypotheses were not accepted. However, SEM evaluation showed that etching with HF $5 \%$ and $10 \%$ during $60 \mathrm{sec}$ created grooves and microcracks on the LD surface possibly due to glassy matrix dissolution and removal of unsupported crystals. Although Posritong, et al., (2013), observed that the structural changes caused by HF after different etching times did not significantly affect the flexural strength of a glass-based veneering ceramic, the results of this study showed that the extension of HF etching time can deeply damage the surface and may weak LD structure (Brentel, et al., 2007; Zogheib, et al., 2011, Cardoso, et al., 2021).

Other studies have also reported that the increase in surface roughness caused by HF etching is associated with a reduction in LD flexural strength (Zogheib, et al., 2011; Hooshmand, et al., 2008). Ramakrishnaiah, et al., (2016), reported that longer HF etching times of silica-based glass-ceramics results in larger, deeper, and irregular grooves due to a significant change in pore pattern, crystal structure, and surface roughness. Therefore, it seems reasonable to follow the HF etching manufacturer's recommendation of $20 \mathrm{sec}$ (Guarda, et al., 2013).

Since different HF concentrations used for 20 -sec etching did not significantly affect the immediate bond strength to resin cement, it is recommended to use 5\% HF to minimize LD damage. The SEM evaluation of this study showed that $5 \%$ HF 
etching for $20 \mathrm{sec}$ dissolved an adequate amount of glassy matrix, which corroborates with previous research (Sundfeld, et al., 2018; Prochnow, et al., 2017). Although no severe or even lethal accidents involving the use of HF in dentistry have been found in the literature, this acid must be used at the current lowest effective concentration of 5\% due to toxicological and biological aspects (Sundfeld, et al., 2018; Trakyali, et al., 2009; Lise, et al., 2015). Since HF is highly volatile and toxic to organic tissues, it can cause injuries to the respiratory or digestive system if when inhaled or ingested (Kalavacharla, et al., 2015). Moreover, its corrosiveness can harm both patients and clinicians soft tissues and eyes, and the severity of injuries is directly associated with the exposure time and HF concentration (Ozcan, et al., 2012).

It is believed that shear stresses are involved in the majority of ceramic restorations failures (Pattanaik \& Wadkar, 2011; Shimada, et al., 2002), thus, the $\mu$ SBS was used in this in vitro study to evaluate the bond strength between resin cement and LD. The choice for micromechanical tests is based on the reduction of specimen size that minimizes the occurrence of cohesive failures and the stress around the adhesive interface is more evenly distributed (Lise, et al., 2015). In addition, the generation of pre-testing stresses at the adhesive interface of $\mu$ SBS specimens is substantially reduced when compared to the specimen preparation for microtensile bond strength test (Panah, et al., 2008). Some authors claim that $\mu$ SBS allows multiple specimens testing on the same ceramic surface (Shimada, et al., 2002).

The results of this research must be carefully interpreted since in vitro studies are carried out in dry and static conditions. The exposition to oral fluid could cause hydrolysis and change the mechanical properties of LD, while changes in temperature and pH could have an influence on bond strength (Venturini, et al., 2015; Pattanaik, et al., 2011).

\section{Conclusion}

The use of 5\% HF for $20 \mathrm{sec}$ is the most appropriate LD etching protocol due to no reduction of bond strength to resin cement, shorter application time, lower risk of toxic/corrosive, and damage to the ceramic structure.

\section{References}

Aboushelib, M. N., \& Sleem, D. (2014). Microtensile bond strength of lithium disilicate ceramics to resin adhesives. J Adhes Dent, 16(6), 547-552. https://doi.org/10.3290/ j.jad.a33249

Alghazzawi, T. F., Lemons, J., Liu, P. R., Essig, M. E., \& Janowski, G. M. (2012). The failure load of cad/cam generated zirconia and glass-ceramic laminate veneers with different preparation designs. J Prosthet Dent, 108(6), 386-393. https://doi.org/10.1016 / s0022-3913 (12) 60198-X

Bajraktarova-Valjakova, E., Grozdanov, A., Guguvcevski, L., Korunoska-Stevkovska, V., Kapusevska, B., Gigovski, N., Mijoska, A., \& BajraktarovaMisevska, C. (2018). Acid etching as surface treatment method for luting of glass-ceramic restorations, part 1: Acids, application protocol and etching effectiveness. Open Access Maced J Med Sci, 6(3), 568-573. https://doi.org/10.3889 / oamjms.2018.147

Blatz, M. B., Sadan, A., \& Kern, M. (2003). Resin-ceramic bonding: A review of the literature. J Prosthet Dent, 89(3), 268-274. https://doi.org/10.1067 / mpr.2003.50

Borges, G. A., Sophr, A. M., de Goes, M. F., Sobrinho, C. L., \& Chan, D. C. N. (2003). Effect of etching and airborne particle abrasion on the microstructure of different dental ceramics. J Prosthet Dent, 89(5): 479-488. https://doi.org/10.1016 / s0022-3913 (02) 52704-9

Bottino, M. A., Snellaert, A., Bergoli, C. D, Özcan, M., Bottino, M. C., \& Valandro, L. F. (2015). Effect of ceramic etching protocols on resin bond strength to a feldspar ceramic. Oper Dent, 40(2), 40-46. https://doi.org/10.2341/13-344-L

Brentel, A. S., Özcan, M., Valandro, L. F., Alarça, L. G., Amaral, R., \& Bottino, M. A. (2007). Microtensile bond strength of a resin cement to feldspathic ceramic after different etching and silanization regimens in dry and aged conditions. Dent Mater, 23(11), 1323-1331. https://doi.org/10.1016 / j.dental.2006.11.011

Cardoso, M. S., Faria, L. F., Lima, C. M., Leite, F. P. P., \& Melo, L. A. (2021). Influência da concentração de condicionamento do ácido hidrofluorídrico na adesão protética de cerâmicas vítreas: uma revisão sistemática. Res., Soc. Dev, 10(2), e7810212093. http://dx.doi.org/10.33448/rsd-v10i2.12093

Denry, I., \& Kelly, J. R. (2014). Emerging ceramic-based materials for dentistry. J Dent Res, 93(12), 1235-1242. https://doi.org/10.1177 / 0022034514553627

Edelhoff, D., Prandtner, O., Saeidi Pour, R., Liebermann, A., Stimmelmayr, M., \& Güth, J. F. (2018). Anterior restorations: The performance of ceramic veneers. Quintessence Int, 49(2), 89-101. https://doi.org/10.3290 / j.qi.a39509 
Gracis, S., Thompson, V. P., Ferencz, J. L., Silva, N.R., \& Bonfante, E. A. (2015). A new classification system for all-ceramic and ceramic-like restorative materials. Int J Prosthodont, 28(3), 227-235. https://doi.org/10.11607 / ijp.4244

Guarda, G. B., Correr, A. B., Gonçalves, L. S., Costa, A. R., Borges, G. A., Sinhoreti, M. A., \& Sobrinho, C. L. (2013). Effects of surface treatments, thermocycling, and cyclic loading on the bond strength of a resin cement bonded to a lithium disilicate glass ceramic. Oper Dent, 38(2), 208-217. https://doi.org/10.2341/11-076-L

Haddad, M. F., Rocha, E. P., \& Assunção, W. G. (2011). Cementation of prosthetic restorations: From conventional cementation to dental bonding concept. J Craniofac Surg, 22(3), 952-958. https://doi.org/10.1097 / SCS.0b013e31820fe205

Hooshmand, T., Parvizi, S., \& Keshvad, A. (2008). Effect of surface acid etching on the biaxial flexural strength of two hot pressed glass ceramics. J Prosthodont, 17(5), 415-419. https://doi.org/10.1111/j.1532- 849X.2008.00319.x

Kalavacharla, V. K., Lawson, N. C., Ramp, L. C., \& Burgess, J. O. (2015). Influence of etching protocol and silane treatment with a universal adhesive on lithium disilicate bond strength. Oper Dent, 40(4), 372-378. https://doi.org/10.2341 / 14-116-L

Lise, D. P., Perdigão, J., Van Ende, A., Zidan, O., \& Lopes, G. C. (2015). Microshear bond strength of resin cements to lithium disilicate substrates as a function of surface preparation. Oper Dent, 40(5), 524-532. https://doi.org/10.2341/14-240-L

Lopes, G. C., Perdigão, J., Baptista, D., \& Ballarin, A. (2019). Does a self-etching ceramic primer improve bonding to lithium disilicate ceramics? Bond strengths and FESEM analyses. Oper Dent, 44(2), 210-218. https://doi.org/10.2341 / 17-355-L

Mokhtarpour, F., Alaghehmand, H., \& Khafri, S. (2017). Effect of hydrofluoric acid surface treatment on microshear bond strength of CAD/CAM ceramics. Electron Physician, 9(10), 5487-5493. https://doi.org/10.19082 / 5487

Mörmann, W. H., Stawarczyk, B., Ender, A., Sener, B., Attin, T., \& Mehl A. (2013). Wear characteristics of current aesthetic dental restorative CAD/CAM materials: Two-body wear, gloss retention, roughness and martens hardness. J Mech Behav Biomed Mater, 20(1), 113-125. https://doi.org/10.1016 / j.jmbbm.2013.01.003

Ozcan, M., Allahbeickaraghi, A., \& Dündar, M. (2012). Possible hazardous effects of hydrofluoric acid and recommendations for treatment approach: A review. Clin Oral Investig, 16(1), 15-23. https://doi.org/ 10.1007 / s00784-011-0636-6

Panah, F. G., Rezai, S. M. S., \& Ahmadian, L. (2008). The influence of ceramic surface treatments on the micro-shear bond strength of composite resin to IPS Empress 2. J Prosthodont,17(5), 409-414. https://doi.org/10.1111/ j.1532- 849X.2007.00296.x

Pattanaik, S., \& Wadkar, A. P. (2011). Effect of etchant variability on shear bond strength of all ceramic restorations -An in vitro study. J Indian Prosthodont Soc, 11(1), 55-62. https://doi.org/10.1007 / s13191-011-0064-y

Peumans, M., Valjakova, E. B., De Munck, J., Mishevska, C. B., \& Van Meerbeek, B. (2016). Bonding effectiveness of luting composites to different CAD/CAM materials. J Adhes Dent, 18(4), 289-302. https://doi.org/10.3290 / j.jad.a36155

Posritong, S., Borges, A. L., Chua, T. M., Eckert, G. J., Bottino, M. A., \& Bottino, M. C. (2013). The impact of hydrofluoric acid etching followed by unfilled resin on the biaxial strength of a glass-ceramic. Dent Mater, 29(11), 281- 290. https://doi.org/10.1016/ j.dental.2013.08.210

Prochnow, C., Venturini, A. B., Grasel, R., Bottino, M. C., \& Valandro, L. F. (2017). Effect of etching with distinct hydrofluoric acid concentrations on the flexural strength of a lithium disilicate-based glass ceramic. Biomater J Biomed Mater Res B Appl, 105(4), 885-891. https://doi.org/10.1002/jbm.b.33619

Puppin-Rontani, J., Sundfeld, D., Costa, A. R., Correr, A. B., Puppin-Rontani, R. M., Borges, G. A., Sinhoreti, M., \& Correr-Sobrinho, L. (2017). Effect of hydrofluoric acid concentration and etching time on bond strength to lithium disilicate glass ceramic. Oper Dent, 42(6), 606-615. https://doi.org/10.2341 / 16215-L

Ramakrishnaiah, R., Alkheraif, A. A., Divakar, D. D., Matinlinna, J. P., \& Vallittu, P. K. (2016). The effect of hydrofluoric acid etching duration on the surface micromorphology, roughness, and wettability of dental ceramics. Int J Mol Sci, 17(6), 822. https://doi.org/10.3390 / ijms17060822

Santos, M. J. M. C., Costa, M. D., Rubo, J. H., Pegoraro, L.F., \& Santos, Jr. G. C. (2015). Current all-ceramic systems in dentistry: a review. Compend Contin Educ Dent, 36(1), 38-40.

Shimada, Y., Yamaguchi, S., \& Tagami, J. (2002). Micro-shear bond strength of dual-cured resin cement to glass ceramics. Dent Mat, 18(5), $380-388$. https://doi.org/10.1016/ s0109-5641 (01) 00054-9

Sundfeld, $\quad$ D., Correr-Sobrinho, $\quad$ L., Pini, $\quad$ N. $\quad$ I., Costa, $\quad$ A. $\quad$ R., Sundfeld, $\quad$ R. $\quad$ H., Pfeifer, $\quad$ C. $\quad$ S., \& Martins, $\quad$ L. $\quad$ R. $\quad$ (2016). The effect of hydrofluoric acid concentration and heat on the bonding to lithium disilicate glass ceramic. Braz Dent J, $27(6)$, 727-733. https://doi.org/10.1590/0103-6440201601024

Sundfeld, D., Palialol, A. R. M., Fugolin, A. P. P., Ambrosano, G. M. B., Sobrinho, C. L., Martins, L. R. M., \& Pfeifer, C. S. (2018). The effect of hydrofluoric acid and resin cement formulation on the bond strength to lithium disilicate ceramic. Braz Oral Res, 32: e43. https://doi.org/10.1590/1807-3107bor2018.vol32.0043 
Research, Society and Development, v. 10, n. 17, e215101724776, 2021 (CC BY 4.0) | ISSN 2525-3409 | DOI: http://dx.doi.org/10.33448/rsd-v10i17.24776

Sundfeld Neto, D., Naves, L. Z., Costa, A. R., Correr, A. B., Consani, S., Borges, G. A., \& Sobrinho, C. L. (2015). The effect of hydrofluoric acid concentration on the bond strength and morphology of the surface and interface of glass ceramics to a resin cement. Oper Dent, 40(5), 470-479. https://doi.org/10.2341 / 14-133-L

Trakyali, G., Malkondu, Ö., Kazazoglu, E., \& Arun, T. (2009). Effects of different silanes and acid concentrations on bond strength of brackets to porcelain surfaces. Eur J Orthod, 31(4), 402-406. https://doi.org/10.1093 / ejo / cjn118

Venturini, A. B., Prochnow, C., Rambo, D., Gundel, A., \& Valandro, L. F. (2015). Effect of hydrofluoridric acid concentration on resin adhesion to a feldspathic ceramic. J Adhes Dent, 17(4), 313-320. https://doi.org/10.3290/j.jad.a34592

Vila-Nova, T., Silva, N. R., Moura, D. M. D. M., Araújo, G. M., Miranda, L. M., Carvalho, I. H. G., Souxa, K. B., Silva, S. E. G. \& Souza, R. O. A. (2019). Cimentação Adesiva em Cerâmicas Vítrias: condicionamento e limpeza pós condicionamento: Parte I. Prótese News, 6(5), 578-590.

Zogheib, L. V., Della Bona, A., Kimpara, E. T., \& Mccabe, J. F. (2011). Effect of hydrofluoric acid etching duration on the roughness and flexural strength of a lithium disilicate-based glass ceramic. Braz Dent J, 22(1), 45-50. https://doi.org/10.1590/S0103-64402011000100008 